\title{
Adverteren doet verkopen
}

Keywords adverteren

In de 'commentaar-rubriek' van de Lancetbelicht Sidney Wolfe het risico van geneesmiddelreclame. Artsen denken dat ze niet worden beïnvloed door reclame; dit is onjuist. Verhaald wordt over een PR-firma die cursussen aanbiedt aan fabrikanten waarin geleerd wordt artsen te overtuigen van de superioriteit van hun product. De firma heeft 'uitgevonden' dat de hippocampus het hersengedeelte is waarlangs het voorschrijven moet worden geprogrammeerd (hetzelfde gedeelte wordt overigens geassocieerd met schizofrenie en posttraumatische stresssymptomen). Namens de Public Citizen's Health Research Group fulmineert de auteur tegen deze misstanden, boos op de industrie die zo handelt en diep teleurgesteld in de gemakkelijk te beïnvloeden artsen.

Hierop reageert iemand van de 'Coalition for Healthcare Communication': De ideeën van Sidney Wolfe zijn simplistisch, alles gaat er verantwoord en ethisch aan toe, de FDA controleert bijna alles tevoren, de geneesmiddelreclame in de VS voldoet aan de hoogste eisen.

Het antwoord van Wolfe bevat interessante gegevens: aan geneesmiddelreclame wordt in de VS twaalf miljard dollar uitgegeven (ca. 40 dollar per Amerikaan). Geneesmiddelreclame wordt zelden of nooit ter goedkeuring voorgelegd aan de FDA. Integendeel, in een recent jaar moest de FDA 163 maal achteraf corrigerend optreden tegen onjuist advertentiemateriaal.

Redactie MFM: Niemand smijt graag geld over de balk, ook de farmaceutische industrie niet. Er wordt dus zoveel geld gestopt in adverteren omdat het omzet oplevert. Geld uitgegeven aan marketing kan niet worden uitgegeven aan research. Negeren van marketing zal dus direct en op de lange termijn de patiënt ten goede komen. Als nieuw echt beter is, hoort $\mathrm{u}$ dat heus wel. Hoe doet de 'gewone arts' dit? Zich baseren op de inleidende hoofdstukken van het Farmacotherapeutisch Kompas, op NHG-standaarden en op het GeneesmiddelenBulletin (en $M F M$ ).

\section{Literatuur}

Wolfe S. Lancet 1996; 348: 662 en 1452.

GeBu 1996; 30: 63-70.

Letter. Lancet 1996; 348: 1452. 